\title{
Universal Social Protection and Health Care as a Social Common
}

\author{
Francine Mestrum ${ }^{1}$
}

Published online: 6 November 2020

(c) Society for International Development 2020

\begin{abstract}
COVID-19 reveals the undeniable fact of our interdependence and some hard truths about our economic system. While this is nothing new, it will now be difficult for all those who preferred to ignore some basic facts to go on with business as usual. Our economy collapsed because people cannot buy more than what they actually need. But as the economy grows the more people get sick and need help. And our universal welfare systems never excluded so many people as they do now. The many flaws in the dominant thinking and policymaking do not only refer to our health systems, but are almost all linked to the way the neoliberal globalization is organized. Turn the thinking around, forget the unfettered profit-seeking, start with the real basic needs of people and all the so badly needed approaches logically fall in the basket: the link with social protection, with water, housing and income security, the link with participation and democracy. In this article, I want to sketch the journey from needs to commons, since that is where the road should be leading us to. It goes in the opposite direction of more austerity, more privatization, more fragmentation of our social policies. It also leads to paradigmatic changes, based on old concepts such as solidarity and a new way to define sustainability.
\end{abstract}

Keywords Commons $\cdot$ Social protection $\cdot$ Health $\cdot$ COVID-19

The COVID-19 crisis is revealing in many aspects. All of a sudden, one does not have to convince people anymore of the importance of health care and social protection. Surprising as it may sound, for many governments and for many social movements, social protection has not been one of the priorities in their agenda. Some think the private sector will take care of it, others think they have to respect the international fiscal directives, and still others give priority to environmental policies with maybe some vague demand for basic income.

If this current crisis could re-direct past thinking into a clear demand for health care and social protection, leaving aside universal basic income and privatizations, one would be able to speak of the silver lining of this coronacrisis. However, in order to so, many traps have to be avoided.

In this article I will briefly look at what sideways can better be left behind, what a forward-looking policy can look like and how it can lead to a perspective on social commons and system change. This implies an intersectional approach to health, social protection and several other sectors of social

Francine Mestrum mestrum@skynet.be

1 Global Social Justice, Brussels, Belgium and economic policies. It is the road to the sustainability of life, people, societies and nature.

\section{Contradictions}

The most contradictory element in this crisis is the amazing awareness that the economy is collapsing because people are only buying what they really need. For those who never were able to do anything else, nothing changed. But at the same time, the economy was growing with every person that had to be taken to hospital, with every funeral that had to be organized and with every videoconference of people unable to meet for real. It shows once again the absurdity of the blind focus on economic growth in terms of Gross Domestic Product (GDP). Should we not cheer instead of deplore the cuts in luxury consumption, and should we not grieve instead of cheer for the growth due to extra funerals?

Due to the economic backlash, the production of pollutants including $\mathrm{CO}_{2}$ and nitrogen oxides dropped between 10 and 30\% from February to June 2020. But even if lockdown measures continue around the world till the end of 2021, global temperatures will only be $0,01^{\circ}$ lower than expected by 2030 (Gohd 2020). In other words, behavioural change 
is not enough. On stock exchanges, there were some ups and downs, but globally shareholders did not suffer. And Jeff Bezos had not enough time to count his extra profits.

In short, while people were suffering and dying, small businesses lost their income and the dominant economic and financial systems just continued, with some slight changes at the margins. Governments put people at risk by giving priority to economic recovery, loosening the confinement measures before the virus had actually disappeared. Hospitals and care workers were suffering-many of health personnel died, in fact! - because of lack of protective equipment, private hospitals were selective in their admissions, some poor countries even lacked the basic hospital beds.

Once again, Naomi Klein's statement, made in another context, that the economy is at war with life was shown to be true (Klein 2014). The only conclusion, then, is that we have to turn our backs to the neoliberal globalization that frames this economic system and look for the exit. But how? The task before us is to reshape our thinking, knowing that the current system cannot solve our problems which are matters of life, of people, of societies and of nature.

\section{Other Ways of Thinking}

Let us try to turn our thinking around and not start from the economy but from people's needs. These needs are the same all over the world: they are food, water, shelter, clothing, housing, health care, clean air... in our modern and urban societies we can add other public services such as education, culture, communication or collective transport. In order to meet all those needs, people rightly want protection and this protection, basically, can only be given in two ways in order to safeguard life: either with strong rules, police and the military, or with a broad range of social protection measures, with economic and social rights. If one believes in the importance of peace, the latter is the way to go.

Now, there obviously are many different ways to try and guarantee that all people's needs are properly met.

Here, I want to briefly mention three ways that cannot lead to lasting and sustainable solutions. I will then point to the many interlinkages and propose the way of social commons, based on solidarity and the possible synergies between all elements of the social, economic and political systems.

\section{Welfare States}

The first solution is the existence of welfare states, as we have seen in several richer countries. If we look back at the way they came about, we can only be full of admiration for the social struggles they implied and the institutional arrangements they led to. Most of them have severely been damaged by the neoliberal cuts in social spending of the last decades, the privatization of health care, pension systems and other public services, and the growing delegitimizing of public collective solidarity. But again, looking at what some countries still have, such as Scandinavia, Germany, France or my own country Belgium, this looks like a miracle compared to the poor or non-existing social protection most people in the Global South have. So why not just promote this system in the rest of the world?

The main reason is that the world has changed compared to the period in which welfare states emerged. Women are now massively on the labour market, there are more and more single parent families, there is more migration and the economic system itself has seriously changed. The growing number of people working in the platform economy hardly have any protection. More and more companies rely on temporary workers with less protection. It is true that these welfare states have seriously hindered the emergence of new poverty, but they did not eradicate poverty since they were focused on formal labour markets and did not touch those outside of them. The economic and social rights they provide now have to be extended and enlarged which means a universal implementation, a reform of labour markets with more rights, the transferability of rights for migrant workers, vocational training, etc.

While the basic principles of welfare states, built on solidarity and social citizenship (Marshall 1964; Castel 1995) remain valid, one has to be critical of their bureaucratization and one has to look for better ways to shape the needed solidarity. Welfare states clearly still have to be promoted, but they need a serious re-examination.

\section{'Western' Modernity and Basic Income}

A second solution to discard is rather popular in some segments of the ecological movement which often puts serious question marks to 'western' modernity and wants to go in the direction of universal basic incomes. In this article I cannot go into the details of this delicate discourse. Let me just say that much has to do with its definition. Based on 'modernization theory' of development studies, implying a linear 'progress' from rural to industrial societies, from subsistence to consumerism, from feudalism to liberal democracies (Rostow 1960), one can feel sympathy for those who reject it. But based on enlightenment thinking with universal human rights, the fundamental equality of all human beings, the separation of religion and state, and maybe most of all the capacity of Kant's 'sapere aude' ('have the courage to know') and of self-criticism, the objections to modernity are more difficult to accept. All too often, anti-modernity leads to fundamentalism, as can be seen in some countries of 
the Middle East. And most of all, most people in the South do want some kind of modernity, from human rights and democracy to mobile phones. What has to be condemned about the 'western' modernity is that it never applied its valid principles to peoples in the South and that colonizers never allowed these people to define and shape their own modernity (Schuurman 1993). The time has certainly come to take into account the 'epistemologies of the South' (de Sousa Santos 2016).

More often than not all those critical of modernity also reject welfare state types of solidarity, as they think it is linked to reformism and productivism. They prefer a universal basic income (UBI), that is an equal amount of money given unconditionally to all members of society. Again, not all arguments in favour and against this solution can be developed here (Downes and Lansley 2018). But there are serious reasons to reject this solution, the main one being that unequal people have to be treated unequally in order to promote equality (Sen 1992). Some have more demands than others and this should be taken into account. Also, giving money to people who do not need it and who in many cases may not even pay taxes, makes this solution extremely expensive, so that it can only be pursued by drastically cutting down on public services such as health care. In fact, indirectly, by providing money to people and cutting social public expenditures, UBI favours the privatization of public services (Mestrum 2016). Finally, one word has to be said about the kind of solidarity universal basic incomes imply. Welfare states organize a horizontal and structural solidarity of all with all, it is a kind of collective insurance. Basic income, on the contrary, implies a vertical solidarity between the state and a citizen, and another citizen, and another citizen. The message to these citizens is, here is your money, now leave us alone. Take care of yourself. In other words, it is a fundamental liberal solution.

Today, there is a lot of semantic confusion around basic incomes. Many people speak about it and want to promote it, while in fact they only mean to introduce a guaranteed minimum income for those who need it, for those who for one reason or another cannot be active on the labour market. This is a totally different kind of solution that certainly can be supported since it offers income security, a crucial element of wellbeing and social protection.

'Social protection' as used in this article is the overarching umbrella concept for different social policies. It includes social security (social insurances against economic and social hazards such as sickness, unemployment, labour accidents... and collective saving systems for old age pensions), social assistance (helping the poor), public services and labour law. Today, for some international organizations, social protection is more or less synonymous with poverty reduction policies, since they gave up on 'universal' systems for all citizens.

\section{Social Protection Floors}

The International Labour Organization adopted a Recommendation in $2012^{1}$ on 'Social Protection Floors'. This is a somewhat simplified and reduced-way of putting meat on the bone of its Convention 102 of 1952 on the minimum standards for social security. ${ }^{2}$ This initiative certainly can be supported and if ever realized, it would mean a huge progress for all people all over the world. But we have to be aware that it is very limited and includes only income security in case of illness, old age and unemployment, maternity and child care, as well as health care. Given the absence of any kind of social protection in many countries, this would indeed mean progress, but it can hardly be seen as a sufficient protection for a life in dignity.

A supplementary reason why some caution is necessary is the fact that the ILO and the World Bank have engaged in a joint initiative for 'universal social protection'. ${ }^{3}$ As we know, it is the World Bank that came out with 'poverty reduction' in 1990 and 'social protection' some twenty years later, all the while refusing to change even one iota to the basics of its neoliberal adjustment policies. The World Bank now proposes a tiered system of social protection, with a limited system for all but more particularly for the poor, presented as a 'poverty prevention package' (Mestrum 2019). They call it 'universal' with their own meaning, that is 'progressive universalism' referring to the 'availability' of benefits when and where they are needed. ${ }^{4}$

All this means that there are few arguments to be against this initiative but that it is important to know it is limited, that it will not stop privatizations, on the contrary. In fact, this kind of social protection is at the service of markets, creating private markets for health and education, and protecting people so they can improve their productivity. At the World Bank, the reasoning behind it is purely economic.

\footnotetext{
${ }^{1}$ ILO, Social Protection Floors Recommendation, R202, 2012, https://www.ilo.org/dyn/normlex/en/f?p=NORMLEXPUB: 12100 :0::NO::P12100_ILO_CODE:R202. Accessed 10 August 2020.

2 ILO, C102 - Social Security (Minimum Standards) Convention, 1952 (No 102), https://www.ilo.org/dyn/normlex/en/f?p=NORML EXPUB:12100:0::NO::P12100_ILO_CODE:C102. Accessed 28 September 2020.

3 ILO and World Bank Group, A shared mission for universal social protection, Concept Note, https://www.ilo.org/wcmsp5/groups/publi c/—dgreports/—dcomm/documents/genericdocument/wcms_37899 6.pdf. Accessed 10 August 2020.

${ }^{4}$ Francine Mestrum, Universalism... Really?, https://socialcommons. eu/2019/01/13/universalism-really/. Accessed 13 August 2020.
} 


\section{Interlinkages}

What then can be the solution? In his 'Contradictions of the welfare state' Claus Offe stated that capitalism does not want any social protection, while at the same time it cannot survive without it (Offe 1984). It is easy to see that World Bank type solutions belong to the part that capitalism cannot do without. They help to maintain the legitimacy of the system and should prevent people to fall in extreme poverty.

One has to look, then, for the objectives of social protection. If one considers it is indeed protection of people, geared toward social justice and peace-mentioned in the Constitution of the $\mathrm{ILO}^{5}$ - we have to leave behind economic thinking and start a journey from the basic needs of people. These universal needs have given rise to the definition of human rights, civil, political, economic, social and cultural rights that governments are bound to respect, protect and fullfil. Food, shelter, clothing, housing, health care ... no one can do without, though the way these needs can be met will differ from one country to another, from one historical period to another. This indicates a first element that will lead to social commons: people have to be involved in the way their social policies are shaped, they know best what is to be done in a given context, at what moment.

Secondly, and taking into account the current coronacrisis, it is obvious that health care is central but will not be enough. If people have no clean water and soap to wash their hands, there is a problem. If people live in slums or are homeless, they cannot be confined with a whole family and children. If they are street vendors, their choice is dying from hunger or dying from a virus. In other words, their health and indeed survival depend on much more than just doctors, hospitals and medicines. Housing, labour, their natural environment and psychological needs play a direct role as well. More in general, if people lack literacy, they cannot read messages on the dangers of junk food. If their incomes are too limited, they have no money for healthy food. If people have good jobs but are exposed to dangerous substances in their factories, they will get ill. If farmers have to use toxic pesticides on their land, they will get ill, and their produce risks to make consumers ill as well.

Thirdly, it is obvious that preventing is so much better than curing. So, if we really want people to live in good health, beyond curing the illnesses they might suffer from, we necessarily have to start looking at the basic elements of social security: people require income security to protect them from distress, fear and want. Next to that, people need good labour laws to provide and protect their jobs

\footnotetext{
${ }^{5}$ ILO Constitution, Preamble: 'Whereas universal and lasting peace can be established only if it is based upon social justice', 1919, www. ilo.org. Accessed 13 August 2020.
}

with decent wages and working hours, with a possibility for collective bargaining, with protections against exposures to dangerous substances and other risks.

People will also need public services, health care, obviously, but also education, housing, transport, communication... as well as environmental policies to provide clean air, water and green spaces. It is obvious that in order to tackle all these problems and solutions, one will also have to look at transnational corporations and at the economic system itself. It becomes clear that in order to have healthy food without toxic residues, and housing at affordable prices, free markets will have to be reined in.

In the quest for the alternatives, amongst others one might look at feminist economics, the notion of putting care in the centre. Can an economy at the service of people and of societies not also be an economy of care, caring for the needs of people, producing what people need? That is why the social and solidarity economy, cooperatives and other forms of co-responsible production can offer a perspective for a better future.

\section{Social Commons ${ }^{6}$}

Where, then, do the commons come in?

According to Dardot and Laval's seminal book on the common (Dardot and Laval 2014), commons are the result of a social and political process of participation and democratic decision-making concerning material and immaterial goods that will be looked at from the perspective of their use value, eliminating or severely restricting private ownership and the rights derived from it. They can concern production as well as re-production, they refer to individual and to collective rights.

Following this definition, social protection systems may broadly speaking be considered to be commons as soon as a local community, or a national organization or a global movement decide to consider them as such, within a local, national or global regulatory framework. If they organize direct citizens' participation in order to find out what these social protection systems should consist of and how they can be implemented, they can shape them in such a way that they fully respond to people's needs and are emancipatory.

Considering economic and social rights as commons, then, basically means to democratize them, to state they belong to the people and to decide on their implementation and on their monitoring. This clearly will involve

\footnotetext{
${ }^{6}$ Part of the following sections are based on Francine Mestrum, Social justice and system change (3), https://socialcommons. eu/2018/05/19/social-justice-and-systemic-change-3/. Accessed 10 August 2020.
} 
a social struggle, because in the past neoliberal decades these rights have been hollowed out, public services have been privatized and labour rights have weakened if not disappeared. Moreover, democratic systems have been seriously weakened and reduced to a bare minimum the real participation of people. While markets have grown, the public sphere has shrunk.

In other words, this approach allows for doing what was mentioned before: people's involvement in shaping and putting in place social protection processes and systems, which look beyond the fragmented narratives of rights, go beyond disease control and develop instead a truly intersectional approach in order to guarantee human dignity and real sustainability.

One of the positive elements in the current COVID crisis has been the flourishing of numerous initiatives of local solidarities and mutual aid, people helping the homeless and their elderly neighbours, caring for the sick, organising open spaces and playing grounds for kids. This help was crucial for overcoming a very difficult period and it might be a good start for further collective undertakings that could indeed lead to more commons.

Taking into account what was said above on the many interlinkages, this might mean, in the health sector, the putting in place of interdisciplinary health centres, where doctors, care workers, social assistants and citizens cooperate in coordinated community campaigns, planning most of all primary care as a specialty.

However, these local actions cannot be a substitute for a more structural approach. Commons are not necessarily in the exclusive hands of citizens and are not only local. States or other public authorities also have to play their role. We will always need public authorities for redistribution, for guaranteeing human rights, for making security rules, etc. It means they are co-responsible for our interdependence. But the authorities we have in mind in relation to enhancing our economic and social rights or our public services will have to be different from what they are today. We know that public authorities are not necessarily democratic, very often they use public services and social benefits as power instruments or for clientelist objectives. That is why the State institutions and public authorities will themselves have to act as a kind of public service, in real support of their citizens.

In the same way, markets will be different. If social protection mechanisms, labour rights and public services are commons, the consequence is not that there is nothing to be paid anymore. People who work obviously have to be paid, even if they work in a non-profit sector. However, prices will not respond to a liberal market logic but to human needs and the use value of what is produced.

So, if we say social commons go beyond States and markets, we do not say they go without States and markets. It will be a different logic that applies.

\section{System Change}

By focusing on the individual and collective dimensions of preventive health care and by directly involving people in shaping public policies, the commons approach can become a strategic tool to resist neoliberalism, privatization and commodification, in short, a tool for system change. It will allow to build a new narrative and develop new practices to better and broader organize people's movements. Shaping commons means building power together with others.

Indeed, health and social protection, geared towards social justice, can be an ideal entry point for working on more synergies, beyond the fragmented approaches of social and economic policies. Today, many alternatives are readily available, all with the objective of preserving our natural environment, stopping climate change, reforming the economy away from extractivism and exploitation, restoring public services. Faced with the hollowing out of our representative democracies, many movements are working on better rules for giving all people a voice that is listened to. Even at the level of international organizations, proposals are made to fight tax havens, illicit financial flows and other mechanisms for tax evasion. There is no need to find a big agreement to include them all, since even separately they all can help to get out of the current system destroying nature and humankind.

Neither is social justice the only entry point or the only road to take. Starting from the environment or from the economy, a comparable road can be taken. What it does suppose is that all roads are taken and followed with 'obstinate coherence', that is followed to the end, till the objective of say, social justice, a care economy, full democracy, human dignity with civil, political, economic, social and cultural rights is reached.

The current COVID crisis puts the focus on health and gives us an opportunity for mapping this road, for indicating its possibilities, for showing all the interlinkages and synergies. It is up to social movements and progressive governments to follow that road,to push for changes in sectors that at first sight are not related to the issue one fights for, but in the end are crucial for it. If one works for social protection, one will have indeed to also point to the importance of clean air and good agricultural practices. It might be rather easy to organize commons at the local level, but it is far more difficult to achieve something at the national, let alone the global level. How to tackle global corporations? What we can do is pointing to the different negative effects of their products and practices and link them to a generally accepted goal. That is the importance of the initiative currently taken at the UN Human Rights Council in order to have binding rules for transnational 
companies to respect human rights. If we want healthy food and if we want to prevent certain types of cancer, we have to ban certain toxic products. It is not easy, the fight will be long and the social struggles may be disrupted at many moments. But is there any other strategy? If we want people to be in good health, in the sense of Alma Ata, ${ }^{7}$ that is ' $a$ state of complete physical, mental and social wellbeing' as a fundamental human right, we not only have to point to the lack of social protection, but also to some practices of global corporations, from Facebook to Bayer. If we want economic and social rights to be respected, we will have to look at building standards and link them to the cheap clothes made available to western consumers.

What will be needed is a broad effort in popular education. In developed countries of Western Europe too many people do not know anymore where social protection systems come from, how social struggles have made them possible, what kind of solidarity is behind them and why collective solidarity is better than an individual insurance. In many countries of the South people do not even know their rights or do not believe they can be really fulfilled. Some experience already exists with political laboratories where public authorities meet with citizens, health and social professionals as well as citizens and their organizations in order to see how to organize and improve social protection systems.

\section{Conclusion}

At a time of urgent health needs and social upheaval in numerous countries, at a moment that right-wing populism, authoritarianism and even fascism are re-emerging, it is also extremely urgent for social movements to get their act together. That means, going beyond the usual protests, developing practical alternatives, be watchdogs for public policies and build alternative narratives and practices. Counter-hegemonic movements are needed, at the local, the national, the regional and the global level. 'Long-term social and political change happens more frequently by setting up and maintaining alternative practices than by protest and armed revolution' (Pleyers 2020).
In short, what is urgently needed is counter-power in an interdependent world. We can start by reclaiming social protection, stating it is ours and bring it back to its major objective: to protect people and societies and to promote sustainability of people, societies and nature.

\section{References}

Castel, Robert. 1995. Les metamorphoses de la question sociale. Unechronique du salariat. Paris: Fayard.

de Sousa Santos, Boaventura. 2016. Epistemologies of the South. London: Routledge.

Dardot, Pierre, and Christian Laval. 2014. Commun. Essaisur la révolution au XXIème siècle, Paris: La Découverte.

Downes, Amy, and Stewart Lansley (eds.). 2018. It's Basic Income. The global debate, Bristol: Policy Press.

Gohd, Chelsea. 2020. Dropped emissions during COVID-19 lockdown will do nothing for climate change, Nature Climate Change, 6 August.

Klein, Naomi. 2014. This Changes Everything: Capitalism vs. the Climate. New York: Simon \& Schuster.

Marshall, T.H. 1964. Class, Citizenship and Social Development. New York: Doubleday and Company Inc.

Mestrum, Francine. 2019. The World Bank and its new social contract. https://socialcommons.eu/2019/12/08/the-world-bank-and-itsnew-social-contract/. Accessed 13 August 2020.

Mestrum, Francine. 2016. The hidden logic of basic income. https:// socialcommons.eu/2016/06/12/the-hidden-logic-of-basic-incom e/. Accessed 13 August 2020.

Offe, Claus, and (John Keane, (eds.). 1984. Contradictions of the Welfare State. London: Hutchinson \& Co.

Pleyers, Geoffrey. 2020. The Pandemic is a Battlefield. Social Movements in the COVID-19 Lockdown. https://doi.org/10.1080/17448 689.2020.1794398. Accessed 13 August 2020.

Rostow, W.W. 1960. The Stages of Economic Growth. Cambridge: Press Syndicate of the University of Cambridge.

Schuurman, F. 1993. Modernity, post-modernity and the New Social Movements. in F. Schuurman, Beyond the Impasse. New directions in development theory, London: Zed Books.

Sen, Amartya. 1992. Inequality Re-examined. Oxford: Clarendon Press.

Publisher's Note Springer Nature remains neutral with regard to jurisdictional claims in published maps and institutional affiliations.

\footnotetext{
7 World Health Organization, Declaration of Alma Ata, 1978, https:// www.who.int/publications/almaata_declaration_en.pdf. Accessed 10 August 2020.
} 